Article

\title{
Antimicrobial Activity of an Extract of Hermetia illucens Larvae Immunized with Lactobacillus casei against Salmonella Species
}

\author{
Kyu-Shik Lee ${ }^{1,+}$, Eun-Young Yun ${ }^{2,+}\left(\mathbb{D}\right.$ and Tae-Won Goo ${ }^{3, *}$ \\ 1 Department of Pharmacology, College of Medicine, Dongguk University, Gyeongju 38766, Korea; \\ there1@dongguk.ac.kr \\ 2 Department of Integrative Bio-Industrial Engineering, Sejong University, Seoul 05006, Korea; \\ yuney@sejong.ac.kr \\ 3 Department of Biochemistry, College of Medicine, Dongguk University, Gyeongju 38766, Korea \\ * Correspondence: gootw@dongguk.ac.kr; Tel.: +82-54-703-7801 \\ $\dagger$ These authors contributed equally to this work.
}

Received: 15 September 2020; Accepted: 13 October 2020; Published: 15 October 2020

check for updates

Simple Summary: In this investigation, we found antimicrobial activity of the extract of Lactobacillus casei-infected Hermetia illucens larvae (HIL) against Salmonella species. The result demonstrates that the extract is a powerful natural antibiotic and preservative.

\begin{abstract}
The expressions of antimicrobial peptides (AMPs) in the larvae of the black soldier fly, Hermetia illucens, were significantly increased by pathogen or stimulant induced innate immunity activation. We immunized $H$. illucens fifth instar larvae with five different Lactobacillus species, that is, Lactobacillus acidophilus, L. brevis, L. casei, L. fermentum, or L. delbrueckii, to induce the mass production of AMPs and selected optimal immune inducers. Antimicrobial activities in hemolymph and H. illucens larvae (HIL) extract were evaluated against three salmonella species (Salmonella pullorum, Salmonella typhimurium, and Salmonella enteritidis). Highest antimicrobial activity was shown by the hemolymph of HIL immunized by L. casei and its activity was closely linked with the inductions of cecropin 1 (HiCec1) and defensin 1 (HiDef1) gene expressions. Furthermore, antimicrobial activity in hemolymph was stable to heat and $\mathrm{pH}$ and the growth of three Salmonella species were dramatically suppressed by HIL hemolymph and extract after immunization with L. casei. The minimal inhibitory concentration (MICs) of L. casei-immunized HIL extract against Staphylococcus aureus, Escherichia coli, and Salmonella species ranged from 100 200 $\mu \mathrm{g} / 100 \mu \mathrm{L}$ and no cytotoxicity to CaCo-2 and L929 cells were observed in the concentration range 100 40,000 $\mu \mathrm{g} / 100 \mu \mathrm{L}$. Taken together, the present investigation demonstrates that $L$. casei-immunized HIL extract is a powerful natural antibiotic and preservative that can prevent contamination by Salmonella species.
\end{abstract}

Keywords: antimicrobial activity; natural antibiotics; antimicrobial peptide; Hermetia illucens; Salmonella

\section{Introduction}

Antibiotics are used to treat infectious diseases and prevent infections in humans and animals and to promote animal growth and thus have played leading roles in the intensive farming of livestock. However, abuse of in-feed antibiotics has caused many problems, such as the appearance of antibiotic-resistant bacteria, antibiotic residues in livestock products, weakening of disease resistance in livestock, and ecosystem pollution [1-3]. To address these problems, the European Union prohibited the use of veterinary antibiotics for growth promotion from 2006, whereas in Korea, after a phased reduction 
from 2005, their usage was banned in July 2011. Nonetheless, antibiotic offtake for treatment purposes is expected to increase due to livestock disease outbreaks caused by the prohibition of veterinary antibiotics in feed. Therefore, novel natural antibiotics are needed to overcome antibiotic-resistant bacteria $[4,5]$.

Insects, such as Hermetia illucens, have evolved innate immune systems that produce potent antimicrobial peptides (AMPs) to protect them from pathogen invasion, and these AMPs are viewed as strong natural antibiotic candidates [6,7]. The insect innate immune system is characterized by cellular and humoral immunity. Cellular immunity involves the phagocytosis of bacteria, fungi, and protozoa, and nodule formation and encapsulation, whereas humoral immunity involves the secretions of proteins and peptides produced in fat and blood cells to hemolymph in response to infection [7-10]. AMPs secreted by the humoral immune response are classified by amino acid sequence and structure as cecropins, defensins, proline-rich peptides, glycine-rich peptides, and lysozymes and are found in various insects including Coleoptera, Diptera, Hymenoptera, and Lepidoptera [11-16]. Melittin is well-known AMP contained in bee venom and its antimicrobial activity was fully elucidated in methicillin-resistant Staphylococcus aureus and Gram-positive and Gram-negative bacteria [17-19]. $H$. illucens survives in organic wastes containing bacterial, fungi, and viruses, and thus produces potent antimicrobials to protect itself against from these entities. Furthermore, $H$. illucens grows rapidly and its feed costs are low, which makes it suitable for the mass production of natural antibiotics. However, $H$. illucens expresses/secretes AMPs in quantity only after innate immune system activation by a pathogen $[20,21]$. Choi et al. previously demonstrated the antibiotic activity of purified peptide extract in hemolymph isolated from $H$. illucens larvae (HIL) immunized by Lactobacillus casei against Klebsiella pneumoniae (ATCC 13883) and Shigella dysenteriae (ATCC 9750) [22]. Here, to select an optimal AMPs inducer, we evaluated antimicrobial activity of HIL immunized with five Lactobacillus species and assessed the bactericidal activities of an extract of HIL immunized with a selected Lactobacillus species to determine the potential use of the extract as a natural antibiotic or preservative.

\section{Materials and Methods}

\subsection{H. illucens Larvae and Bacteria Strains}

HIL were gifted by the Department of Agricultural Biology at the National Institute of Agricultural Sciences of the Rural Development Administration (Wanju, Korea). Animals were maintained at room temperature (RT, $26 \pm 1^{\circ} \mathrm{C}$ ) and 60\% RH. Five Lactobasillus species, that is, L. acidophilus (KCCM 12419), L. brevis (KCCM 10553), L. casei (KCCM 12413), L. fermentum (KCCM 11441), and L. delbrueckii (KCCM 35463), were obtained from the Korean Collection for Type Culture (Wanju, Korea) and used to activate the innate immune system of H. illucens. The antimicrobial activity of HIL hemolymph was assessed using the Gram-positive bacterium S. aureus (KCCM 40881) and the Gram-negative bacteria Escherichia coli (KCCM 11234) and Salmonella pullorum (KVCC-BA0702509), Salmonella typhimurium (KCCM 40406), and Salmonella enteritidis (KCCM 12021), which were also obtained from the National Institute of Animal Science of the Rural Development Administration (Wanju, Korea).

\subsection{Immunization of HIL}

Using a fine needle (diameter $0.35 \mathrm{~mm}$, length $40 \mathrm{~mm}$ ), $10^{1}$ to $10^{9} \mathrm{cfu} / \mathrm{mL}$ of Lactobacillus species were inoculated into $H$. illucens fifth instar larvae by abdominal puncture and then the larvae were held on RT for 2, 4, 8, 16, 24, 48, or $72 \mathrm{~h}$ with starvation. Hemolymph was isolated and assessed for antimicrobial activity and AMP mRNA expressions.

\subsection{Preparation of HIL Extracts}

Immunized HIL were dried for 45 min using a by microwave and ground to a powder, which was suspended in $20 \%$ acetic acid solution, boiled for $30 \mathrm{~min}$, and centrifuged at $4500 \mathrm{rpm}$ for $30 \mathrm{~min}$ at 
$4{ }^{\circ} \mathrm{C}$. Supernatant was collected, dried for $9 \mathrm{~h}$ in vacuum-spin drier, and resuspended in sterilized distilled-water as HIL extract.

\subsection{Evaluation of the Antimicrobial Activities in HIL Hemolymph and Extract}

The antimicrobial activities of HIL extracts were assessed using a radial diffusion assay (RDA) using Gram-positive Staphylococcus aureus and Gram-negative Escherichia coli, S. pullorum, S. typhimurium, and $S$. enteritidis. To perform RDA, autoclaved underlay gel [ $9 \mathrm{mM}$ sodium phosphate, $1 \mathrm{mM}$ sodium citrate, $\mathrm{pH} 7.4,1 \%$ low electroendosmosis agar, and $0.03 \%$ tryptic soy broth (TSB)] was mixed with each bacterium and hardened in a $100 \mathrm{~mm}$ square plate. Then, we prepared $3.5 \mathrm{~mm}$-diameter of well onto underlay gel and $10 \mu \mathrm{L}$ of hemolymph or extract of HIL was injected into the well. The underlay gel was held at $37^{\circ} \mathrm{C}$ for $3 \mathrm{~h}$ and then covered with a sterilized overlay gel $(6 \%$ TSB and $1 \%$ low electroendosmosis agar). Gel plates were incubated for $18 \mathrm{~h}$ at $37^{\circ} \mathrm{C}$, and antimicrobial activities were assessed by measuring the widths of clear zones.

\subsection{Determination of Minimum Inhibitory Concentrations (MICs) of HIL Extracts}

Firstly, we determined $\mathrm{cfu} / \mathrm{mL}$ of each bacterial by serial tittering and then measured absorbance of each $\mathrm{cfu} / \mathrm{mL}$ at $600 \mathrm{~nm}$. Then, S. aureus and E. coli were used to determine the MICs of extracts obtained after immunization with L. casei. Determination of MICs was also used for evaluation of antimicrobial activity against Salmonella species. Bacteria, such as S. aureus, E. coli, S. pullorum, S. typhimurium, and S. enteritidis, were inoculated into liquid medium, respectively, and grown at $37^{\circ} \mathrm{C}$ for $18 \mathrm{~h}$ in a shaking incubator (shaking speed: $200 \mathrm{rpm}$ ), and then further cultured to $4 \times 10^{6} \mathrm{cfu} / \mathrm{mL}$ over $2.5 \mathrm{~h}$ under the same conditions. A total of $90 \mu \mathrm{L}\left(1 \times 10^{6} \mathrm{cfu} / \mathrm{mL}\right)$ of bacterial culture mixtures were transferred to a 96-well plate and $10 \mu \mathrm{L}$ of serially diluted extracts were then added to wells and incubated at $37^{\circ} \mathrm{C}$ for $18 \mathrm{~h}$. Absorbances were measured at $600 \mathrm{~nm}$ to determine MICs. Melittin was purchased from Sigma-Aldrich; Merck KGaA (Darmstadt, Germany) was used as control.

\subsection{Analysis of AMPs Transcription}

Lactobacillus-infected HIL were held at RT for defined times and then total RNA was extracted. First-strand cDNA was synthesized using a high capacity reverse transcription kit (Applied Biosystems, Waltham, MA, USA), and the cDNA obtained was assessed for the gene expressions of cecropin 1 (HiCec1) and defensin 1 (HiDef1). Primers for HiCec1 and HiDef1 were designed using the Primer 3 program (http://simgene.com/Primer3; accessed on 13 June, 2016) and gene expressions were normalized versus the Drosophila melanogaster actin 5C (DmAct5C) gene. Primer sequences are provided in Table 1.

Table 1. Primer sequences used to analyze cecropin 1 and defensin 1 gene expressions by real-time PCR.

\begin{tabular}{ccc}
\hline \multicolumn{2}{c}{ Name } & Sequences \\
\hline \multirow{2}{*}{ HiCec1 } & Forward & 5'-TTGGTCAACGAGTTCGTGATGC-3' \\
& Reverse & 5'-TCCTTGTTGTGGTGGTCCACCT-3' \\
\hline \multirow{2}{*}{ HiDef1 } & Forward & 5'-AGGTGGTGGAGCAGCATTAC-3' \\
& Reverse & 5'-ACGACGTCCCAAAGCAATAC-3' \\
\hline \multirow{2}{*}{ Act5C } & Forward & 5'-AAGGACTCGTACGTGGGTG-3' \\
& Reverse & 5'-CATCTTCTCACGGTTGGC-3' \\
\hline
\end{tabular}

\subsection{Cytotoxicity Analysis by MTT Assay}

We investigated the cytotoxicity of Lactobacillus-immunized HIL extract using CaCo-2 human intestinal cells and L929 mouse fibroblasts. Cells were seeded in a 96-well plates and allowed to attached for $24 \mathrm{~h}$ in a $5 \% \mathrm{CO}_{2}$ atmosphere at $37^{\circ} \mathrm{C}$. Then, culture medium was removed and then cells were treated with $180 \mu \mathrm{L}$ of various concentrations of Lactobacillus-immunized HIL extract 
$(0 \sim 5000 \mu \mathrm{g} / 100 \mu \mathrm{L})$ or melittin $(0 \sim 32 \mu \mathrm{g} / \mu \mathrm{L})$ for $24 \mathrm{~h}$. Cells were then administered $20 \mu \mathrm{L}$ of $5 \mathrm{mg} / \mathrm{mL}$ MTT reagent and left for $4 \mathrm{~h}$ in the dark. Media were then carefully discarded and $200 \mu \mathrm{L}$ of DMSO was added to each well to dissolve the formazan. Absorbances were measured at $540 \mathrm{~nm}$ using an ELISA reader.

\subsection{Statistical Analysis}

The analysis was performed using the Student's $t$-test and one-way analysis of variance. Experiments were independently performed at least three times, and results are presented as means \pm standard deviations (SDs). $p$-value of less than 0.05 was regarded as statistically different.

\section{Results}

\subsection{Optimization of Lactobacillus Species for the Mass Production of AMPs in H. illucens}

We used five types of Lactobacillus to activate the innate immune system of H. illucens. RDA results showed normal HIL hemolymph did not exhibited antimicrobial activity against E. coli or S. aureus (Figure 1). Furthermore, we did not observed death of any HIL infected by Lactobacillus species (data not shown). In contrast, although the induction of antimicrobial activity was depended on Lactobacillus species type, increased antimicrobial activities to $E$. coli and $S$. aureus were observed in the hemolymph of Lactobacillus-immunized HIL (Figure 1). Highest antimicrobial activity against E. coli and S. aureus were observed for the hemolymph of L. casei-infected larvae, and notably, this was greater than that of Enterococcus faecalis (KACC 11859) or Serratia marcescens (KACC 11961) challenged larvae (Figure 1) [23]. Therefore, L. casei was chosen as an activator of the innate immune system of H. illucens.

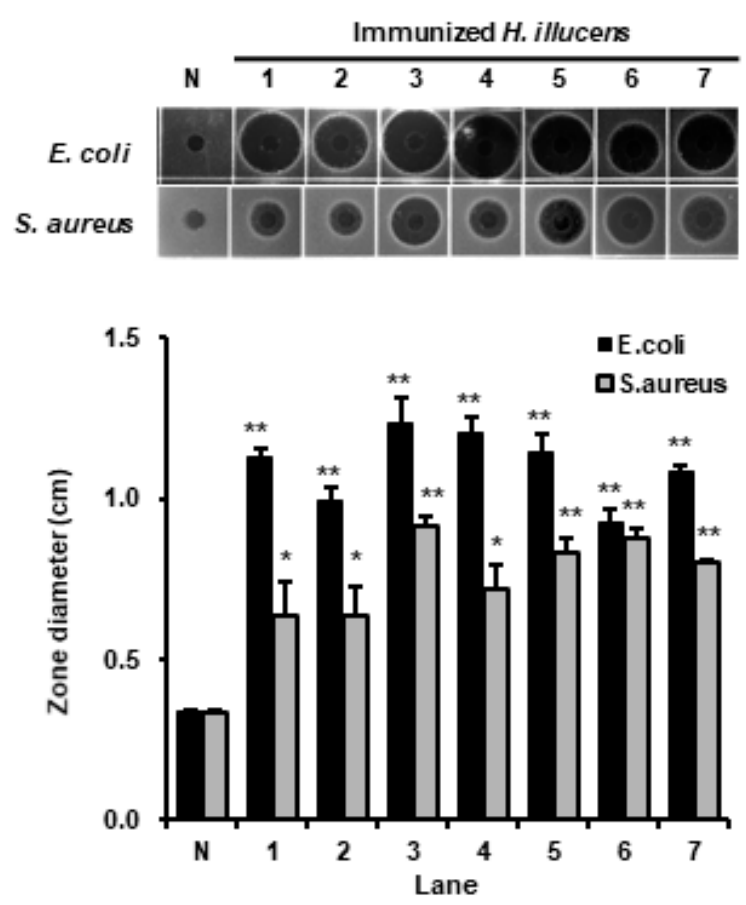

Figure 1. Comparison of antimicrobial activities to E. coli and S. aureus in the hemolymph of HIL immunized with E. faecalis, S. marcescens, L. acidophilus, L. brevis, L. casei, L. fermentum, or L. delbrueckii. $\mathrm{N}$ indicates non-immunized hemolymph of H. illucens. Lane 1, hemolymph of S. marsescen-immunized HIL; lane 2, hemolymph of E. faecalis-immunized HIL; lane 3, hemolymph of L. casei-immunized HIL; lane 4, hemolymph of L. acidophilus-immunized HIL; lane 5, hemolymph of L. brevis-immunized HIL; lane 6, hemolymph of L. fermentum-immunized HIL; lane 7, hemolymph of L. delbrueckii-immunized HIL. The values of column graphs are presented as the mean \pm S.D. ${ }^{*}$ and ${ }^{* *}$ indicate $p<0.05$ and $p<0.01$ vs. normal control $(\mathrm{N})$, respectively. 


\subsection{Determination of Optimal Conditions for the Mass Production of AMPs}

The results obtained showed that antimicrobial activity in hemolymph was increased by L. casei infection in a concentration-dependent manner (Figure 2A). We also evaluated changes in antimicrobial activity over the time after L. casei infection. As shown in Figure 2B, highest activity was observed at $24 \mathrm{~h}$ after infection. Furthermore, the gene expressions of HiCec1 and HiDef1 (major AMPs produced by H. illucens) peaked at $24 \mathrm{~h}$ (Figure 2C). This result showed that the antimicrobial activity of L. casei-infected HIL hemolymph was closely linked with the induced gene expressions of HiCec1 and HiDef1.

A

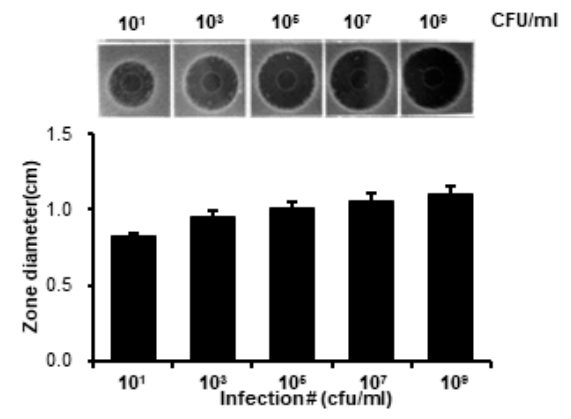

B
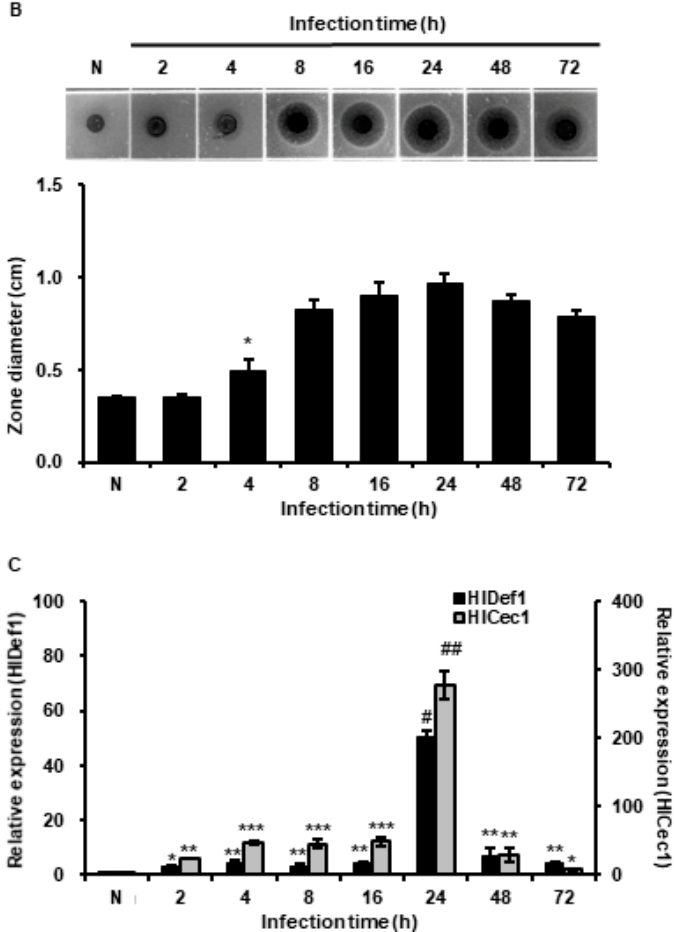

Figure 2. Determination of optimal conditions to produce L. casei-immunized H. illucens larvae (HIL) with highest antimicrobial activity. (A) Evaluation of antimicrobial activities at different L. casei concentrations. We infected HIL with $10^{1}$ to $10^{9} \mathrm{cfu} / \mathrm{mL}$ of $L$. casei to determine the optimal concentration for the mass production of AMPs. The activity in L. casei-immunized HIL hemolymph increased in a concentration-dependent manner. The values of column graphs are presented as the mean \pm S.D. (B) Evaluation of antimicrobial activities at different incubation times after L. casei infection. Highest hemolymph activity of L. casei-immunized HIL occurred at 24 h. (C) Assessment of HiCec1 and HiDef1 mRNA expressions. HiCec1 and HiDef1 gene expressions in L. casei-immunized HIL hemolymph were evaluated at 2, 4, 8, 16, 24, 48 and $72 \mathrm{~h}$ after infection. (A,B) Radial diffusion assay (RDA) was performed with E. coli. (B,C) The values of column graphs are presented as the mean \pm S.D. ${ }^{*}, * *, * *$, \# and \#\# indicate $p<0.05, p<0.01, p<0.005, p<0.001$ and $p<0.00001$ vs. normal control (N), respectively. 


\subsection{Analysis of the Antimicrobial Activities of HIL Hemolymph against Salmonella Species}

We investigated the antimicrobial activities of L. casei-immunized HIL hemolymph against three Salmonella species using RDA. Salmonella species are pathogens parasitic on gut and major causes of food poisoning. In fact, $75 \%$ of food poisoning cases are due to Salmonella species, and reductions in livestock productivity are closely associated with Salmonella contamination [24,25]. We found that the antimicrobial activities of HIL hemolymph against S. enteritidis, S. typhimurium, and S. pullorum were dramatically enhanced by L. casei-immunization and that their activities were greater than that of $1 \mu \mathrm{g}$ of melittin (Figure 3A). Furthermore, the antimicrobial activity of L. casei-immunized HIL hemolymph was maintained after heating $\left(60,70,80\right.$, or $\left.90^{\circ} \mathrm{C}\right)$ for $24 \mathrm{~h}$ and over the $\mathrm{pH}$ range $2 \sim 10$ (Figure $3 \mathrm{~B}, \mathrm{C}$ ). We also found that antimicrobial activity of hemolymph was lowest at $\mathrm{pH} 7.0$ (Figure 3C). These results suggest that AMPs produced by L. casei-immunized HIL effectively suppress the growth of Salmonella species and is stable to heat and a wide $\mathrm{pH}$ range.
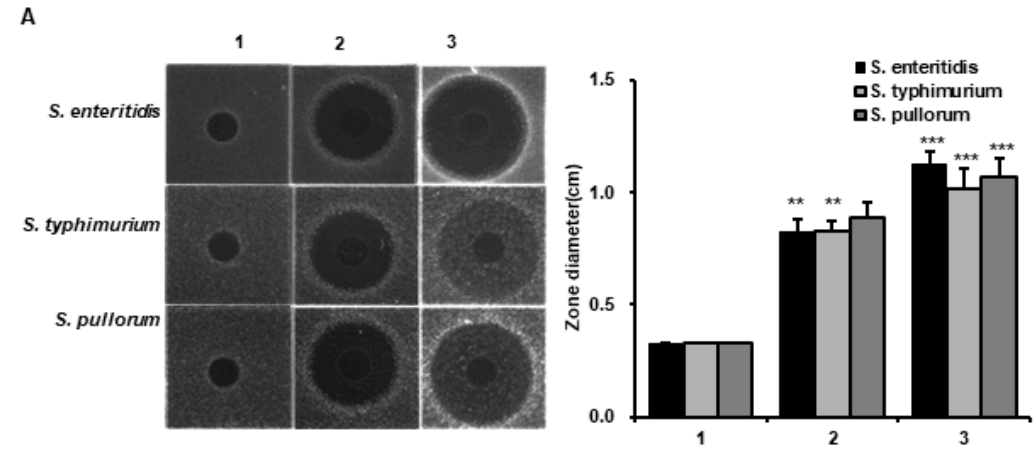

B
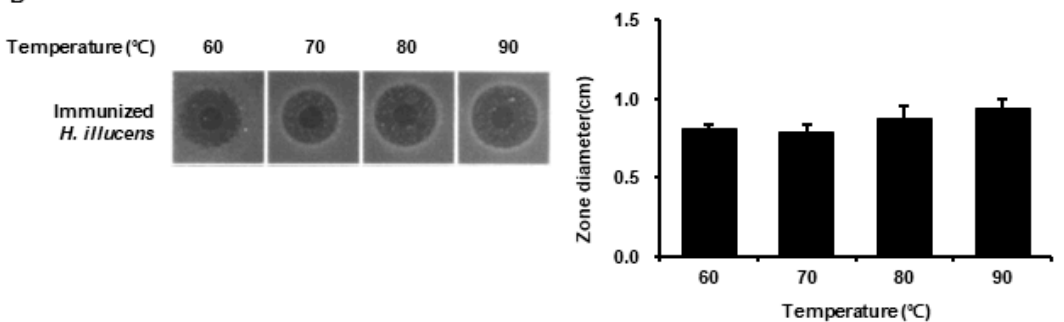

c
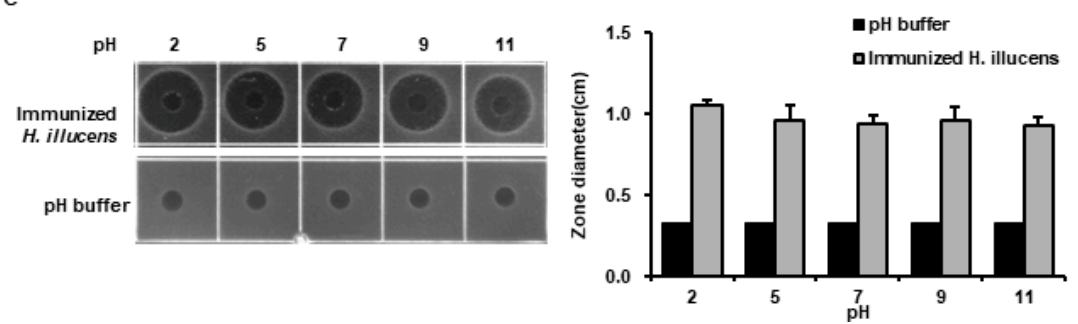

Figure 3. Evaluations of antimicrobial activities to S. enteritidis, S. typhimurium and S. pullorum and of the heat and $\mathrm{pH}$ stabilities of L. casei-immunized HIL hemolymph as determined by RDA. (A) Antimicrobial activities of L. casei-immunized HIL hemolymph against S. enteritidis, S. typhimurium, and S. pullorum. Lane 1, non-immunized HIL hemolymph; lane 2, melittin (1 $\mu \mathrm{g})$; lane 3, L. casei-immunized HIL hemolymph. The values of column graphs are presented as the mean \pm S.D. ${ }^{* *}$ and ${ }^{* * *}$ indicate $p<0.01$ and $p<0.005$ vs. lane 1 , respectively. (B) Thermal stabilities of the antimicrobial activities of hemolymphs. Hemolymphs were incubated at $60,70,80$, or $90^{\circ} \mathrm{C}$ for $24 \mathrm{~h}$. (C) pH stabilities of antimicrobial activity of $L$. casei-immunized HIL hemolymph. A total of $2 \mu \mathrm{L}$ of Hemolymphs was

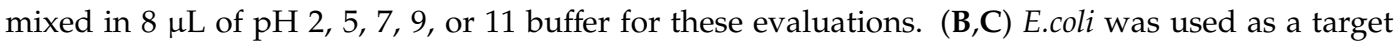
bacterium to confirm antimicrobial activity of L. casei-immunized HIL hemolymph. 


\subsection{Determination of the MICs of L. casei-Immunized HIL Extract}

We investigated whether L. casei-immunized HIL extract has the potential to be used as a natural antibiotic or feed additive with antimicrobial activity. Antimicrobial activities were evaluated by determining MICs against E. coli and S. aureus. The MIC range of melittin to E. coli and S. aureus was $7 \sim 10 \mu \mathrm{g} / 100 \mu \mathrm{L}$ and the L. casei-immunized HIL extract had an MIC range of 100 200 $\mu \mathrm{g} / 100 \mu \mathrm{L}$ (Figure 4A,B). The result reveals that both bacteria, Gram-negative E. coli and Gram-positive S. aureus, show same sensitivity to antimicrobial substances in the extract. Although MICs of the extract were greater than that of melittin, the manufacturing cost of L. casei-immunized HIL extract is much lower than that of melittin, and thus, the extract is more cost-effective.

A

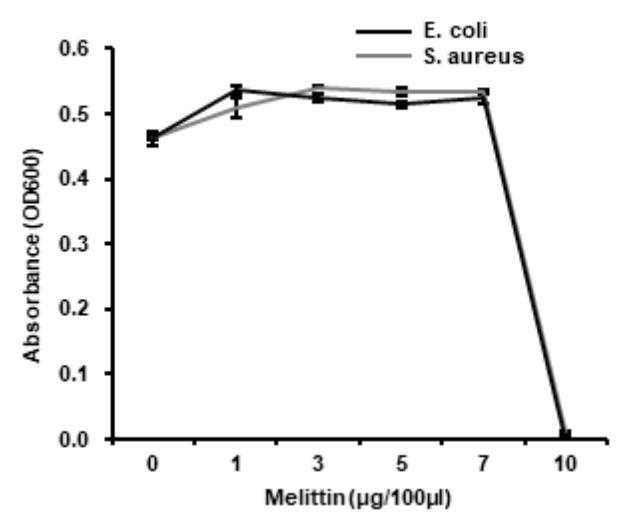

B

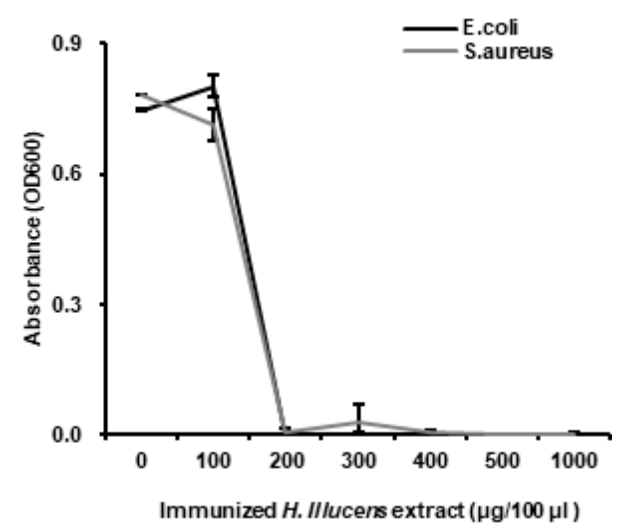

Figure 4. Determination of the minimal inhibitory concentrations (MICs) of melittin (A) and L. casei-immunized HIL extract (B). Various concentrations of $10 \mu \mathrm{L}$ melittin or $10 \mu \mathrm{L}$ L. casei-immunized HIL extract $(10 \mu \mathrm{L})$ were mixed with $90 \mu \mathrm{L}$ of liquid media containing $1 \times 10^{6} \mathrm{cfu} / \mathrm{mL}$ of E. coli or $S$. aureus and incubated at $37^{\circ} \mathrm{C}$ for $24 \mathrm{~h}$.

\subsection{Analysis of the Antimicrobial Activities of L. casei-Immunized HIL Extract against Salmonella Species}

We assessed the antimicrobial activities of L. casei-immunized HIL extract against S. enteritidis, S. typhimurium, and S. pullorum by determining MICs. The results obtained showed that th MICs of melittin to Salmonella species were $10 \mu \mathrm{g} / 100 \mu \mathrm{L}$ and at a concentration of $>200 \mu \mathrm{g} / 100 \mu \mathrm{L}$ the extract completely blocked the growth of all Salmonella species (MICs range 100 200 $\mu \mathrm{g} / 100 \mu \mathrm{L}$ ) (Figure 5A,B).

A

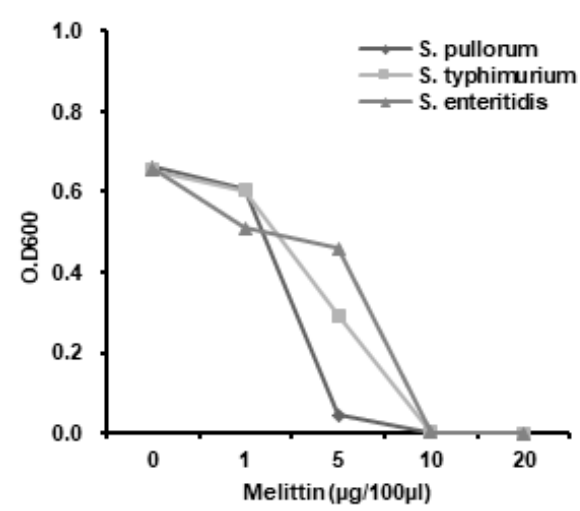

B

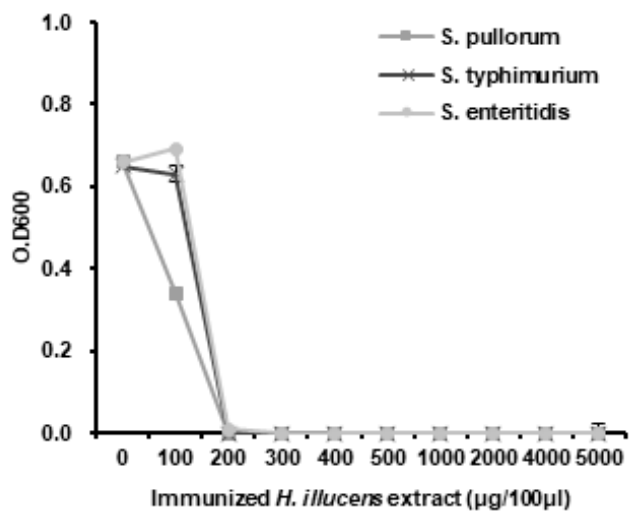

Figure 5. Antimicrobial activities of L. casei-immunized HIL extract against S. enteritidis, S. typhimurium and S. pullorum. Various concentrations of $10 \mu \mathrm{L}$ melittin (A) or $10 \mu \mathrm{L} \mathrm{L}$. casei-immunized HIL extract (B) were mixed with $90 \mu \mathrm{L}$ of liquid media containing $1 \times 10^{6} \mathrm{cfu} / \mathrm{mL}$ of $S$. enteritidis, S. typhimurium, or S. pullorum and incubated at $37^{\circ} \mathrm{C}$ for $24 \mathrm{~h}$. 


\subsection{Analysis of the Cytotoxicities of L. casei-Immunized HIL Extracts to Mammalian Cells}

The cytotoxic effects of antimicrobial in human and animals are key obstacles to clinical, livestock, and feed applications. Therefore, we examined the cytotoxic activities of melittin and of L. casei-immunized HIL extract in CaCo-2 and L929 cells (human intestinal and cell mouse fibroblast cell lines, respectively). No cytotoxic effect was observed on against CaCo-2 and L929 cells at extract concentrations from 100 to $4000 \mu \mathrm{g} / 100 \mu \mathrm{L}$ or from 100 to $2000 \mu \mathrm{g} / 100 \mu \mathrm{L}$, respectively (Figure 6A). In contrast, although cell survival was not reduced by melittin at 1 to $4 \mu \mathrm{g} / 100 \mu \mathrm{L}$, it was found to have potent cytotoxic effects at $>8 \mu \mathrm{g} / 100 \mu \mathrm{L}$ (Figure 6B).

A

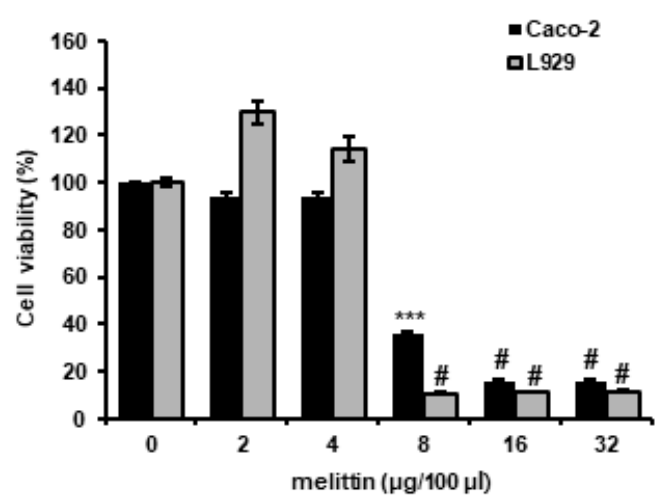

B

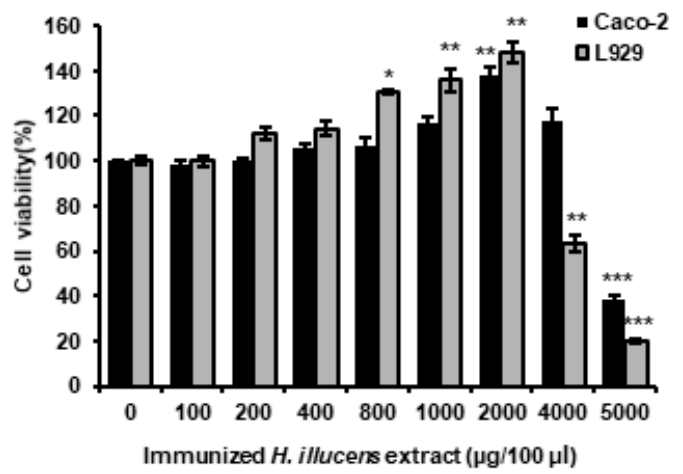

Figure 6. Evaluation of cytotoxic effects of melittin (A) or L. casei-immunized HIL extract (B). $(\mathbf{A}, \mathbf{B}) 1 \times 10^{4}$ cells were seeded into wells, allowed to attach for $24 \mathrm{~h}$, and then cultured with various concentrations of melittin or L. casei-immunized HIL extract for $24 \mathrm{~h}$. The values of column graphs are presented as the mean \pm S.D. ${ }^{*},{ }^{* *},{ }^{* *}$ and \# indicate $p<0.05, p<0.01, p<0.005$, and $p<0.001$ vs. 0 $\mu \mathrm{g} / 100 \mu \mathrm{L}$, respectively.

\section{Discussion}

Synthetic antibiotics and antimicrobials have contributed to public health and promoted the growth of livestock. However, overuse and abuse of antibiotics and antimicrobial drugs are now known to be important causes of drug-resistant bacteria, which threaten public and livestock health. Natural antibiotics, especially AMPs, are considered as promising novel candidates for overcoming drug-resistance [26]. Several investigations have demonstrated insects manufacture AMPs and that these acts as potent natural antibiotics $[7,11,12,27]$. One investigation showed that a HIL extract prevented growth of plant pathogens and suggested its use as a natural antimicrobial [28]. Furthermore, Lactobacillus species activated innate immune response in insects and contributed to reduction of susceptibility in pathogen infected-insects [29-32]. In this investigation, we also found HIL extract immunized with L. casei exhibited antimicrobial activity against three Salmonella species (Figure 4B), which demonstrates that this extract offers a potential means of preventing and treating plant pathogen infections and protecting against Salmonella contamination.

In general, insect AMPs are induced when the innate immune system is activated and are present at much lower levels under normal conditions. In this investigation, we used five Lactobacillus species to activate the innate immunity system. As shown Figure 1, highest antimicrobial activities against Gram-positive S. aureus and Gram-negative E. coli were observed in the hemolymph of L. casei-infected H. illucens, and these activities were higher than those observed for the hemolymphs of HIL challenged by E. faecalis or S. marcescens (Figure 1). E. faecalis and S. marcescens are well known human and animal pathogens $[33,34]$. Although these bacteria also effectively activated the innate immune system of $H$. illucens, they pose risks to human and animal health. In contrast, L. casei is a beneficial bacterium in human and its use induced significant increases in HiCec1 and HiDef1 levels and superior antimicrobial activity in the hemolymph and the extract of HIL (Figures 2 and 4). Furthermore, we found that the 
antimicrobial activity of hemolymph was stable for $24 \mathrm{~h}$ over the temperature range $\left(60-90{ }^{\circ} \mathrm{C}\right)$ and the $\mathrm{pH}$ range $(\mathrm{pH} 2-11$ ) (Figure $3 \mathrm{~B}, \mathrm{C})$. In addition, the extract of HIL immunized with L. casei did not adversely affect the survival of L929 or CaCo-2 cells at concentrations up to $2000 \mu \mathrm{g} / 100 \mu \mathrm{L}$ or $4000 \mu \mathrm{g} / 100 \mu \mathrm{L}$, respectively (Figure 6A). These results demonstrate that L. casei-immunized HIL offer a safe antibiotic candidate for the treatment of bacterial infections in human and livestock and for food preservation.

Melittin is major component of bee venom and has been reported to be a powerful antimicrobial against human and animal pathogens and against methicillin-resistant S. aureus [17,35,36]. However, the production cost of melittin and purified bee venom is very high and their applications in the medical and food industries are limited by cytotoxic effects on normal cells and allergic responses (Figure 6B) [37]. In the present study, cytotoxic concentration of melittin to Caco-2 and L929 were dramatically lower than MIC to E. coli and S. aureus (Figure 6B). In contrast, L. casei-immunized HIL extract could be produced cheaply and this extract proved to be relatively non-toxic to normal animal cells (Figure 6A). In fact, the MICs of L. casei-immunized HIL extract to E. coli and S. aureus were 20to 50-fold lower than those to normal animal cells (Figures $4 \mathrm{~A}$ and $6 \mathrm{~A}$ ). Consequently, the present investigation shows that L. casei-immunized HIL extract provides a potential cost-effective means of producing a natural antibiotic with applications in medicine and livestock. However, the allergic effects of this extract have yet to be investigated.

To prevent Salmonella contamination and growth, synthetic preservatives, such as ethylparaben, methylparaben, benzoice acid, sorbic acid, and propanoic acid, are added to foodstuffs, including meat products [38]. Although synthetic preservatives are effective and economical, many have reported harmful effects [39], and thus, there is a considerable demand for a safe and economical natural preservative. We report the hemolymph and extract of L. casei-immunized HIL exhibit powerful antimicrobial activities against three Salmonella species (S. enteritidis, S. typhimurium and S. pullorum) as determined by RDA and MIC assays (Figures 3 and 5). Furthermore, L. casei-immunized HIL extract was non-toxic to normal animal cells at concentrations up to $4000 \mu \mathrm{g} / 100 \mu \mathrm{L}$ (Figure $6 \mathrm{~A}$ ). Our results demonstrate that L. casei-immunized HIL extract should be considered a potential natural preservative for the prevention of food poisoning caused by Salmonella species and a functional feed additive that promotes livestock growth.

\section{Conclusions}

Summarizing, we show that Lactobacillus can be used as an AMP inducer in HIL and that the extract of L. casei-immunized HIL prevents the growth of Salmonella species without inducing cytotoxicity in normal animal cells. Furthermore, the antimicrobial activity of L. casei-immunized HIL extract remained stable over the temperature $\left(60-90{ }^{\circ} \mathrm{C}\right)$ for $24 \mathrm{~h}$ and the $\mathrm{pH}$ range $(\mathrm{pH} 2-11)$, respectively. In conclusion, the present investigation reveals that L. casei-immunized HIL extract is a potent natural antibiotic and preservative with potential applications the medical, food, and livestock industries.

Author Contributions: K.-S.L. and E.-Y.Y. performed the experiments, analyzed the data, and prepared the manuscript. T.-W.G. directed the study and was involved in all aspects of the experimental design, data analysis and manuscript preparation. All authors have read and agreed to the published version of the manuscript.

Funding: This study was supported by the Bio-industry Technology Development Program (318018-3), Ministry for Food, Agriculture, Forestry and Fisheries, Republic of Korea, and by the Basic Science Research Program through the National Research Foundation of Korea (NRF) funded by the Ministry of Education (2020R1F1A1075607).

Conflicts of Interest: The authors have no conflict of interest to declare. 


\section{References}

1. Looft, T.; Johnson, T.A.; Allen, H.K.; Bayles, D.O.; Alt, D.P.; Stedtfeld, R.D.; Sul, W.J.; Stedtfeld, T.M.; Chai, B.; Cole, J.R. In-feed antibiotic effects on the swine intestinal microbiome. Proc. Natl. Acad. Sci. USA 2012, 109, 1691-1696. [CrossRef] [PubMed]

2. Baltzer, S.A.; Brown, M.H. Antimicrobial peptides-promising alternatives to conventional antibiotics. J. Mol. Microbiol. Biotechnol. 2011, 20, 228-235. [CrossRef] [PubMed]

3. Barton, M.D. Antibiotic use in animal feed and its impact on human healt. Nutr. Res. Rev. 2000, 13, $279-299$. [CrossRef] [PubMed]

4. Kang, H.; Seo, O.; Choi, H.; Chae, H.; Na, J.; Bang, H.; Kim, D.; Park, S.; Kim, M.; Jung, S. Effect of dietary supplementation of chlorella powder on production performances, blood components. In Proceedings of the Korean Journal of Poultty Science 27th Regular Conference, Daejeon, Korea, 12 November 2010; pp. $106-108$.

5. Yoo, J.; Park, G.H.; Sung, J.S.; Song, H.; Shin, S.Y.; Jung, W.H.; Heo, J.M. Feed additives in broiler diets to produce healthy chickens without in-feed antimicrobial compounds. Korean J. Agric. Sci. 2014, 41, 441-453. [CrossRef]

6. Kalsy, M.; Tonk, M.; Hardt, M.; Dobrindt, U.; Zdybicka-Barabas, A.; Cytrynska, M.; Vilcinskas, A.; Mukherjee, K. The insect antimicrobial peptide cecropin A disrupts uropathogenic Escherichia coli biofilms. NPJ Biofilm. Microbiomes 2020, 6, 1-8. [CrossRef]

7. Wu, Q.; Patočka, J.; Kuča, K. Insect antimicrobial peptides, a mini review. Toxins 2018, 10, 461. [CrossRef]

8. Boman, H.G. Peptide antibiotics and their role in innate immunity. Annu. Rev. Immunol. 1995, 13, 61-92. [CrossRef]

9. Brogden, K.A. Antimicrobial peptides: Pore formers or metabolic inhibitors in bacteria? Nat. Rev. Microbiol. 2005, 3, 238-250. [CrossRef]

10. Hoffmann, J.A.; Kafatos, F.C.; Janeway, C.A.; Ezekowitz, R. Phylogenetic perspectives in innate immunity. Science 1999, 284, 1313-1318. [CrossRef]

11. Casteels, P.; Ampe, C.; Rivière, L.; Van Damme, J.; Elicone, C.; Fleming, M.; JACOBS, F.; Tempst, P. Isolation and characterization of abaecin, a major antibacterial response peptide in the honeybee (Apis mellifera). Eur. J. Biochem. 1990, 187, 381-386. [CrossRef]

12. Goo, T.-W.; Yun, E.-Y.; Kim, S.-W.; Choi, K.-H.; Kang, S.-W.; Kwon, K.-S.; Yu, K.; Kwon, O.-Y. Bombyx mori protein disulfide isomerase enhances the production of nuecin, an antibacterial protein. BMB Rep. 2008, 41, 400-403. [CrossRef] [PubMed]

13. Goo, T.W.; Yun, E.Y.; Kim, S.W.; Choi, K.H.; Kang, S.W.; Kwon, K.; Choi, J.-S.; Kwon, O.-Y. Secretion of the antibacterial recombinant protein enbocin. Z. Nat. C 2008, 63, 284-288. [CrossRef] [PubMed]

14. Kim, S.-R.; Lee, E.-M.; Yoon, H.-J.; Choi, Y.-S.; Yun, E.-Y.; Hwang, J.-S.; Jin, B.-R.; Lee, I.-H.; Kim, I.-S. Antibacterial Activity of Peptides Synthesized Based on the Bombus ignites abaecin, A Novel Proline-Rich Antimicrobial Peptide. Int. J. Ind. Entomol. 2007, 14, 147-150.

15. Otvos, L., Jr. Antibacterial peptides isolated from insects. J. Pept. Sci. Off. Publ. Eur. Pept. Soc. 2000, 6, 497-511.

16. Zasloff, M. Antimicrobial peptides of multicellular organisms. Nature 2002, 415, 389-395. [CrossRef] [PubMed]

17. Choi, J.H.; Jang, A.Y.; Lin, S.; Lim, S.; Kim, D.; Park, K.; Han, S.M.; Yeo, J.H.; Seo, H.S. Melittin, a honeybee venom-derived antimicrobial peptide, may target methicillin-resistant Staphylococcus aureus. Mol. Med. Rep. 2015, 12, 6483-6490. [CrossRef] [PubMed]

18. Dosler, S.; Gerceker, A.A. In vitro activities of antimicrobial cationic peptides; melittin and nisin, alone or in combination with antibiotics against Gram-positive bacteria. J. Chemother. 2012, 24, 137-143. [CrossRef]

19. Pashaei, F.; Bevalian, P.; Akbari, R.; Bagheri, K.P. Single dose eradication of extensively drug resistant Acinetobacter spp. in a mouse model of burn infection by melittin antimicrobial peptide. Microb. Pathog. 2019, 127, 60-69. [CrossRef]

20. Choi, Y.-C.; Park, K.-H.; Nam, S.-H.; Jang, B.-G.; Kim, J.-H.; Kim, D.-W.; Yu, D.-J. The effect on growth performance of chicken meat in broiler chicks by dietary supplementation of black soldier fly larvae, Hermetia illucens (Diptera: Stratmyidae). J. Sericultural Entomol. Sci. 2013, 51, 30-35. [CrossRef]

21. Park, S.-I.; Kim, J.-W.; Yoe, S.M. Purification and characterization of a novel antibacterial peptide from black soldier fly (Hermetia illucens) larvae. Dev. Comp. Immunol. 2015, 52, 98-106. [CrossRef] 
22. Choi, W.H.; Choi, H.J.; Goo, T.W.; Quan, F.S. Novel antibacterial peptides induced by probiotics in Hermetia illucens (Diptera: Stratiomyidae) larvae. Entomol. Res. 2018, 48, 237-247. [CrossRef]

23. Park, K.; Yun, E.-Y.; Park, S.-W.; Goo, T.-W. The antimicrobial activity of bacterial-challenged black soldier fly, Hermetia illucens. J. Life Sci. 2016, 26, 1409-1414. [CrossRef]

24. Kim, A.; Lee, Y.J.; Kang, M.S.; Kwag, S.I.; Cho, J.K. Dissemination and tracking of Salmonella spp. in integrated broiler operation. J. Vet. Sci. 2007, 8, 155-161. [CrossRef]

25. Olsen, S.J.; MacKinon, L.C.; Goulding, J.S.; Bean, N.H.; Slutsker, L. Surveillance for Foodborne-Disease Outbreaks, United States, 1993-1997; U.S. Department of Health \& Human Servieces: Atlanta, GA, USA, 2000.

26. Bahar, A.A.; Ren, D. Antimicrobial peptides. Pharmaceuticals 2013, 6, 1543-1575. [CrossRef]

27. Vetterli, S.U.; Zerbe, K.; Müller, M.; Urfer, M.; Mondal, M.; Wang, S.-Y.; Moehle, K.; Zerbe, O.; Vitale, A.; Pessi, G. Thanatin targets the intermembrane protein complex required for lipopolysaccharide transport in Escherichia coli. Sci. Adv. 2018, 4, eaau2634. [CrossRef] [PubMed]

28. Park, K.H.; Kwak, K.W.; Nam, S.H.; Choi, J.Y.; Lee, S.; Kim, H.; Kim, S.H. Antibacterial activity of larval extract from the black soldier fly hermetia illucens (diptera: Stratiomyidae) against plant pathogens. J. Entomol. Zool. Stud. 2015, 3, 176-179.

29. Rossoni, R.D.; Fuchs, B.B.; De Barros, P.P.; Velloso, M.d.S.; Jorge, A.O.C.; Junqueira, J.C.; Mylonakis, E. Lactobacillus paracasei modulates the immune system of Galleria mellonella and protects against Candida albicans infection. PLoS ONE 2017, 12, e0173332. [CrossRef]

30. Daisley, B.A.; Trinder, M.; McDowell, T.W.; Welle, H.; Dube, J.S.; Ali, S.N.; Leong, H.S.; Sumarah, M.W.; Reid, G. Neonicotinoid-induced pathogen susceptibility is mitigated by Lactobacillus plantarum immune stimulation in a Drosophila melanogaster model. Sci. Rep. 2017, 7, 2703. [CrossRef]

31. Nishida, S.; Ono, Y.; Sekimizu, K. Lactic acid bacteria activating innate immunity improve survival in bacterial infection model of silkworm. Drug Discov. Ther. 2016, 10, 49-56. [CrossRef]

32. Jorjão, A.L.; de Oliveira, F.E.; Leão, M.V.P.; Jorge, A.O.C.; de Oliveira, L.D. Effect of Lactobacillus rhamnosus on the response of Galleria mellonella against Staphylococcus aureus and Escherichia coli infections. Arch. Microbiol. 2018, 200, 383-389. [CrossRef]

33. Fiore, E.; Van Tyne, D.; Gilmore, M.S. Pathogenicity of Enterococci. Gram-Posit. Pathog 2019, 378-397.

34. Khanna, A.; KhAnnA, M.; AggArWAl, A. Serratia marcescens-a rare opportunistic nosocomial pathogen and measures to limit its spread in hospitalized patients. J. Clin. Diagn. Res. JCDR 2013, 7, 243. [PubMed]

35. Perumal Samy, R.; Gopalakrishnakone, P.; Thwin, M.; Chow, T.; Bow, H.; Yap, E.; Thong, T. Antibacterial activity of snake, scorpion and bee venoms: A comparison with purified venom phospholipase A2 enzymes. J. Appl. Microbiol. 2007, 102, 650-659. [CrossRef]

36. Leandro, L.F.; Mendes, C.A.; Casemiro, L.A.; Vinholis, A.H.; Cunha, W.R.; Almeida, R.d.; Martins, C.H. Antimicrobial activity of apitoxin, melittin and phospholipase A2 of honey bee (Apis mellifera) venom against oral pathogens. An. Acad. Bras. Ciências 2015, 87, 147-155. [CrossRef]

37. Lee, Y.J.; Kang, S.J.; Kim, B.M.; Kim, Y.J.; Woo, H.D.; Chung, H.W. Cytotoxicity of honeybee (Apis mellifera) venom in normal human lymphocytes and HL-60 cells. Chem. Biol. Interact. 2007, 169, 189-197. [CrossRef]

38. Xiu-Qin, L.; Chao, J.; Wei, Y.; Yun, L.; Min-Li, Y.; Xiao-Gang, C. UPLC-PDAD analysis for simultaneous determination of ten synthetic preservatives in foodstuff. Chromatographia 2008, 68, 57-63. [CrossRef]

39. Anand, S.; Sati, N. Artificial preservatives and their harmful effects: Looking toward nature for safer alternatives. Int. J. Pharm. Sci. Res. 2013, 4, 2496.

Publisher's Note: MDPI stays neutral with regard to jurisdictional claims in published maps and institutional affiliations.

(C) 2020 by the authors. Licensee MDPI, Basel, Switzerland. This article is an open access article distributed under the terms and conditions of the Creative Commons Attribution (CC BY) license (http://creativecommons.org/licenses/by/4.0/). 